\title{
RADIAL ARTERY- A MORPHOMETRIC STUDY FOR CLINICAL APPLICATION
}

\section{Raviprasanna.K.H ${ }^{1}$, Aditya Krishna Das *2.}

${ }^{1}$ Assistant Professor, Department of Anatomy, Sree Narayana Institute of Medical Sciences, Chalakka, North Kuthiathode post, Ernakulam, Kerala, India.

${ }^{* 2}$ Assistant Professor, Department of Anatomy, Sree Narayana Institute of Medical Sciences, Chalakka, North Kuthiathode post, Ernakulam, Kerala, India.

\section{ABSTRACT}

Introduction: Knowledge regarding the course and termination of the radial artery before harvesting it for coronary artery bypass graft surgery (CABGS) is important. The brachial artery terminates at the neck of radius into radial and ulnar arteries. The radial artery at wrist is commonly used to feel the pulse by clinicians.

Purpose of the study: To know the available length of the radial artery for CABG.

Materials and Methods: The study included 50 upper limb specimens from Department of Anatomy, Sree Narayana Institute of Medical Sciences, Ernakulam. The specimens were fixed with $10 \%$ neutral buffered formalin solution and the radial artery was measured in forearm till wrist joint.

Results: The mean length of radial artery from the origin of radial recurrent branch to origin of superficial palmar branch was $21.64 \mathrm{cms}$ and the mean distance from interepicondylar line of humerus to the bifurcation of brachial artery was $3.17 \mathrm{cms}$ with a range of 1.3 to $5.1 \mathrm{cms}$.

Conclusion: The present study has revealed the available length of the radial artery which can be used for CABG.

KEY WORDS: Radial artery, Bifurcation, Interepicondylar line.

Address for Correspondence: Dr. Aditya Krishna Das, Assistant Professor, Department of Anatomy, Sree Narayana Institute of Medical Sciences, Chalakka, North Kuthiathode post, Ernakulam, Kerala683594, India. Phone no- +918589851223. Fax No-+91484-2478093.E-Mail: adityakdas@gmail.com

\begin{tabular}{|c|c|c|}
\hline \multicolumn{3}{|c|}{ Access this Article online } \\
\hline \multirow{2}{*}{ Quick Response code } & \multicolumn{2}{|c|}{$\begin{array}{l}\text { Web site: International Journal of Anatomy and Research } \\
\qquad \text { ISSN 2321-4287 } \\
\text { www.ijmhr.org/ijar.htm }\end{array}$} \\
\hline & $\begin{array}{l}\text { Received: } 09 \text { June } 2017 \\
\text { Peer Review: } 09 \text { June } 2017 \\
\text { Revised: None }\end{array}$ & $\begin{array}{l}\text { Accepted: } 18 \text { Jul } 2017 \\
\text { Published (O): } 31 \text { Aug } 2017 \\
\text { Published (P): } 31 \text { Aug } 2017\end{array}$ \\
\hline
\end{tabular}

\section{INTRODUCTION}

The brachial artery bifurcates into radial and ulnar arteries at the level of neck of radius medial to the tendon of biceps brachii. The radial artery runs along the lateral side of forearm till the wrist, where it is palpable between flexor carpi radialis medially \& anterior border of radius laterally. It is accompanied by a pair of venae comitantes and lies superficially, covered by skin \& superficial fascia in major portions except the proximal part, where it is overlapped by brachioradialis muscle. The radial artery enters palm by passing through anatomical snuff box and space between $1^{\text {st }}$ dorsal interosseous muscle to form deep palmar arch [1]. Branches of the radial artery includes radial recurrent, superficial palmar branch and muscular branches. Radial artery was first used as conduit for CABG in 1973 by Carpentier [2]. 15 years later Carpentier et al., revised radial artery grafts again in 1989 when grafts were found patent in control angiography. Acar [3], 
Calafiore [4] \& Possati [5] reported superior long term patency rates for radial artery grafts compared to saphenous vein grafts perhaps because the radial artery is of good size and easier to anastomose sequentially than several of the other conduits. The quality of radial arteries for CABG was improved because of use of ultrasonic harmonic scalpel [HS] (Ethicon endo-surgery, Inc. Cincinnati, $\mathrm{OH}$ ) as an adjunct to or substitute for electrocautery, lasers \& sharp dissection procedures which reduced the thermal damage and vessel spasm $[6,7]$. The knowledge of morphometric measurements of radial artery is useful when harvesting radial artery for CABG.

\section{MATERIALS AND METHODS}

50 previously dissected upper limb specimens were used in the present study, which were used to educate medical undergraduate students at Sree Narayana Institute of Medical Sciences, Ernakulam. The specimens were fixed with $10 \%$ neutral buffered formalin solution. Radial artery was exposed and traced in the cubital fossa and forearm by cleaning the connective tissue around it and its branches were noted down. The following landmarks were marked for identification and measurement. Interepicondylar line of humerus was considered as Point - A. Bifurcation of brachial artery as Point - B, Point- C at origin of radial recurrent branch from radial artery and Point - $\mathbf{D}$ at the origin of superficial palmar branch of radial artery. The distance from point $A$ to $B$ and point $C$ to $D$ was measured with the help of vernier calipers, thread and scale.

Fig. 1: Showing the landmarks for measuring the length of brachial artery from Interepicondylar line of humerus to its bifurcation.

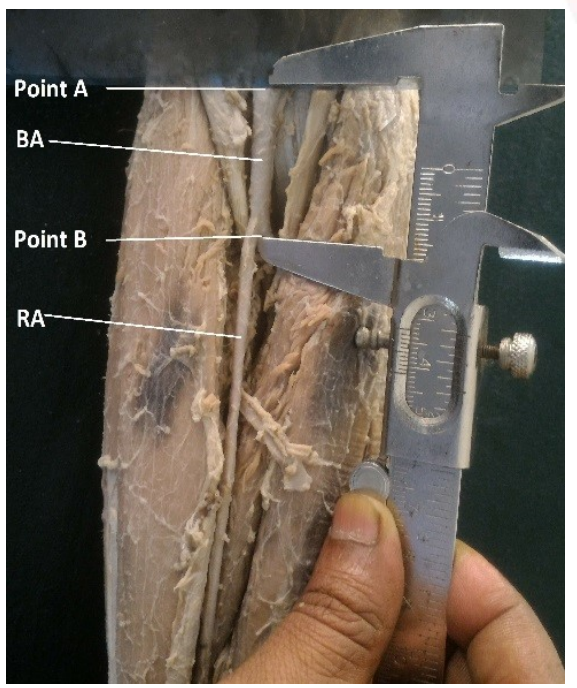

Fig. 2: Showing the landmarks for measuring the length of radial artery from origin of radial recurrent branch to origin of superficial palmar branch of radial artery in the forearm.

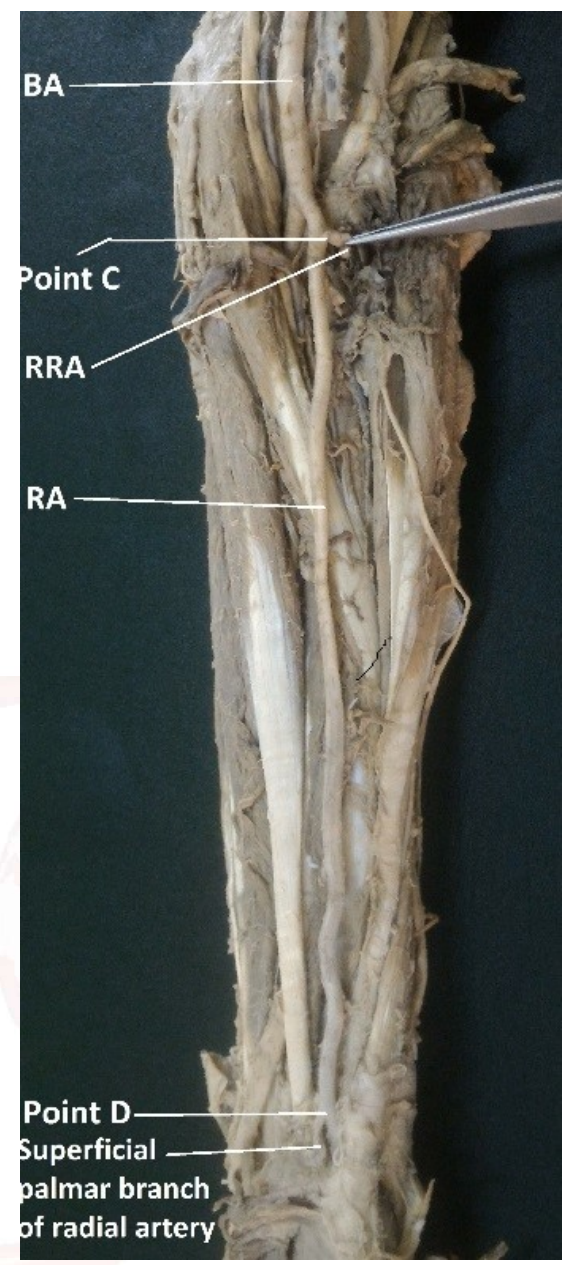

\section{OBSERVATIONS}

The observations of the present study done on 50 upper limb specimens are shown in tables 1 to 4 . Table- 1 shows the level of bifurcation of brachial artery into radial and ulnar arteries from interepicondylar line of humerus in right and left sides. The brachial artery bifurcated into radial and ulnar arteries at neck of the radius in 49 specimens and in one specimen brachial artery bifurcated in the arm and the length of radial artery from the origin of radial recurrent artery to the origin of superficial palmar branch in that specimen was measured to be $25.7 \mathrm{cms}$. Table2 shows the mean distance from intercondylar line of the humerus to the bifurcation of brachial artery which was $3.17 \mathrm{cms}$ with a range of 1.3 to $5.1 \mathrm{cms}$ with standard deviation of 0.73 . Table- 3 shows the length of radial artery from radial recurrent to superficial palmar branch near the wrist in right and left limbs. The mean length of radial artery from the origin of radial recurrent 
branch to origin of superficial palmar branch was $21.64 \mathrm{cms}$, with range of $12.2-25.7 \mathrm{cms}$ and standard deviation of 2.32 (Table: 4).

Table 1: Level of bifurcation of brachial artery from intercondylar line.

\begin{tabular}{|c|c|c|}
\hline Range & $1.1-3 \mathrm{~cm}$ & $3.1-6 \mathrm{~cm}$ \\
\hline Right & 12 & 12 \\
\hline Left & 11 & 14 \\
\hline Total & 23 & 26 \\
\hline
\end{tabular}

Table 2: Distance from intercondylar line to bifurcation of brachial artery.

\begin{tabular}{|c|c|c|c|c|}
\hline & Number & Mean $(\mathrm{cm})$ & S.D & Range $(\mathrm{cm})$ \\
\hline Right & 24 & 3.19 & 0.85 & $1.3-5.1$ \\
\hline Left & 25 & 3.156 & 0.61 & $2.1-4.3$ \\
\hline Total & 49 & 3.173 & 0.73 & $1.3-5.1$ \\
\hline
\end{tabular}

Table 3: Length of radial artery from radial recurrent to superficial palmar branch of radial artery.

\begin{tabular}{|c|c|c|c|}
\hline Range & $10.1-20 \mathrm{~cm}$ & $>20 \mathrm{~cm}$ & Total \\
\hline Right & 3 & 22 & 25 \\
\hline Left & 4 & 21 & 25 \\
\hline Total & 7 & 43 & 50 \\
\hline
\end{tabular}

Table 4: Length of radial artery from radial recurrent branch to superficial palmar branch of radial artery.

\begin{tabular}{|c|c|c|c|c|}
\hline Side & Number & Mean $(\mathrm{cm})$ & S.D & Range $(\mathrm{cm})$ \\
\hline Right & 25 & 21.55 & 2.88 & $12.2-25.7$ \\
\hline Left & 25 & 21.728 & 1.65 & $19.1-24.7$ \\
\hline Total & 50 & 21.64 & 2.32 & $12.2-25.7$ \\
\hline
\end{tabular}

\section{DISCUSSION}

The use of radial artery for coronary bypass grafting is advantageous because of its length, corresponding diameter to coronary arteries and decreased incidence of hypoperfusion syndrome as seen with internal thoracic artery [8] \& [3]. The average length of radial artery from patients varied from $18 \mathrm{cms}$ to $22 \mathrm{cms}$ and the inner diameter spans between 0.2 to $0.3 \mathrm{cms}$ [9]. The radial artery is a thick-walled muscular artery, representative of Guo-Wei He's classification type III (limb artery) [10]. When compared with other vascular conduits, the RA provides additional benefits. According to observational studies relative to saphenous vein grafts, RA can be harvested without interfering with ambulation and their use has been shown to be protective against both early and late mortality and morbidity resulting in enhanced late survival $[11,12]$. Also, unlike SV grafts, RA grafts are adapted to higher arterial pressures and have a homogeneous caliber free from internal valves, characteristics possibly contributing to the RA's superior results. Compared with other arterial grafts, contraindications such as obesity, diabetes mellitus or previous laparotomy do not apply to RA harvesting, allowing this conduit to be harvested in a majority of patients. When comparing the right internal thoracic artery to the radial artery as a second arterial graft, patients receiving a RA have a lower incidence of sternal wound infection and decreased transfusion requirement, though there is no difference in perioperative or intermediate-term cardiac morbidity or mortality rates [13].

Furthermore, RA use is safe in patients with moderate to severe left ventricular dysfunction [14] and in patients over the age of 65 [15]. The presence of a smooth muscle layer in the arterial wall helps the conduit to adjust its caliber to the coronary flow in the native vessels, creating less turbulence at the distal anastomosis $[16,17]$. Before harvesting the $R A$, it is mandatory to assess the adequacy of the ulnar collateral circulation to the hand to avoid ischemia. Methods to detect adequate forearm collateral flow include the Allen test, Static and Dynamic doppler testing and Direct digit pressure measurement during RA compression, and Oxymetric plethysmography together with the computation of a perfusion index [18].

\section{CONCLUSION}

The radial artery is a common artery used for coronary bypass graft surgery. Knowledge about the origin, course and length of radial artery have significant importance in revascularization of coronary arteries and microsurgical techniques in reconstruction of hand.

\section{ABBREVIATIONS:}

CABG - Coronary artery bypass grafting,

BA - Brachial artery,

RA - Radial artery,

Point A - Interepicondylar line of humerus,

Point B - Bifurcation of brachial artery,

Point C - Origin of radial recurrent branch,

Point D - Origin of superficial palmar branch.

Conflicts of Interests: None 


\section{REFERENCES}

[1]. STANDRING S, ELLIS H, HEALY JC, JOHNSON D, WILLIAMS A, COLLINS P, WIGLEY C. Gray's Anatomy, 39th Ed. 2005 Elsevier Churchill Livingstone, New York, pp 883;925-929.

[2]. A Carpentier, JL Guermonpez, A Deloche, C Frechette, C DuBost. The aorta-to-coronary radial artery bypass graft: a technique avoiding pathological changes in grafts. Ann Thorac Surg 1973;16:11121.

[3]. Acar C, Jebara VA, Portoghese M, Beyssen B, Pagny $J Y$, Grare $P$ et al. Revival of the radial artery for coronary artery bypass grafting. Ann Thorac Surg 1992;54:652-60.

[4]. Calaiore AM, Di Giammarco N, Luciani N, Maddestra N, Di Nadro E, Angelini R. Composite arterial conduits for wider arterial myocardial revascularization. Ann Thorac Surg 1994;58:185-190.

[5]. Possati G, Gsudino M, Alessandrini F, Trani C, Glieca $F$, Mazzari $M$, et al. Long term results of radial artery used for myocardial revascularization. Circulation 2003;108:1350-1354.

[6]. Meharwal ZS, Trehan N. Functional status of the hand after radial artery harvesting: results in 3,977 cases. Ann Thorac Surg 2001;72:1557-61.

[7]. Tanemote K, Kanaoka Y, Marakami T, Karoki K. Harmonic Scalpel in coronary artery bypass grafting. J Cardio-vasc. Surg.1992;39:493-495.

[8]. Nitin R Mudiraj, Manisha R Dhobale. Morphometric study of radial artery. International Journal of Recent Trends in Science And Technology, 2015;15(1):06-10. ISSN 2277-2812 E-ISSN 22498109.

[9]. Acar C, Jebara VA, Portoghese M, Fontaliran F, Dervanian $P$, Chachques JC, et al. Comparative anatomy and histology of the radial artery and the internal thoracic artery. Implication for coronary artery bypass. Surg Radiol Anat 1991;13:283-88.
[10]. He G-W, Yang C-Q. Comparison among arterial grafts and coronary artery: an attempt at functional classification. J Thorac Cardiovasc Surg 1995;109:70715.

[11]. Cohen G, Tamariz MG, Sever JY, et al. The radial artery versus the saphenous vein graft in contemporary CABG: a case-matched study. Ann Thorac Surg. 2001;71:180-86.

[12]. Hata M, Seevanayagam S, Manson N, et al. Radial artery 2000: risk analysis of mortality for coronary bypass surgery with radial artery. Ann Thorac Cardiovasc Surg. 2002;8:354-357.

[13]. Borger MA, Cohen G, Buth KJ, et al. Multiple arterial grafts: radial versus right internal thoracic arteries. Circulation. 1998;98(suppl):II7-II14.

[14]. Fazel S, Mallidi HR, Pelletier MP, et al. Radial artery use is safe in patients with moderate to severe left ventricular dysfunction. Ann Thorac Surg. 2003;75:1414-1421.

[15]. Modine T, Al-Ruzzeh S, Mazrani W, et al. Use of radial artery graft reduces the morbidity of coronary artery bypass graft surgery in patients aged 65 years and older. Ann Thorac Surg. 2002;74:1144-1147.

[16]. Deb, S., Cohen, E.A., Singh, S.K., Une, D., Laupacis, A. and Fremes, S.E. (2012) Radial Artery and Saphenous Vein Patency More than 5 Years after Coronary Artery Bypass Surgery: Results from RAPS (Radial Artery Patency Study). Journal of the American College of Cardiology, 2012;60:28-35.

[17]. Desai, N.D., Cohen, E.A., Naylor, C.D. and Fremes, S.E. (2004) A Randomized Comparison of Radial-Artery and Saphenous-Vein Coronary Bypass Grafts. The New England Journal of Medicine 2004;351:23022309.

[18]. Tatoulis J, Buxton BF, Fuller JA. Bilateral radial artery grafts in coronary reconstruction: technique and early results in 261 patients. Ann Thorac Surg. 1998;66:714-720.

\author{
How to cite this article: \\ Raviprasanna.K.H, Aditya Krishna Das. RADIAL ARTERY- A \\ MORPHOMETRIC STUDY FOR CLINICAL APPLICATION. Int J Anat \\ Res 2017;5(3.2):4208-4211. DOI: 10.16965/ijar.2017.286
}

